[Aus dem staatl. Institute für Herstellung von Diphtherieheilserum (Prof. R. Paltauf) und dem chemischen Laboratorium (Prim. E. Freund) der k. k. Krankenanstalt „Rudolfsstiftung“" in Wien.]

\title{
Untersuchungen über das Typhus-Agglutinin und die agglutinirbare Substanz der Typhusbacillen.
}

Von

Dr. Heinrich Winterberg.

Die Kenntniss von der Agglutination der Mikroorganismen unter dem Einflusse homologer Sera ist in der letzten Zeit soweit gefördert worden, dass dieser anfangs ganz wunderbare Vorgang mit allen seinen Erscheinungen einer einheitlichen Auffassung unterworfen werden kann.

Die Entdeckung der specifischen Niederschläge, die Beobachtung, dass Eiweissfallungen in bakterienhaltigen Medien zur Klärung derselben unter Häufchenbildung und Immobilisirung der frei oder molekular beweglichen Keime führen, haben Kraus und Seng ${ }^{1}$ zu der durch eine Reihe zweckentsprechender Versuche gestützten Theorie geführt, dass die Niederschlagsbildung als gemeinsames physikalisches Princip sowohl der specifischen, als auch der nicht specifischen Agglutination zu Grunde liegen dürfte.

Hat nun auch die Kenntniss von dem Mechanismus des Agglutinationsvorganges letzteren unserem Verständnisse näher gebracht, so sind damit bei weitem nicht alle Probleme erschöpft, die derselbe einschliesst.

Insbesondere harren die folgenden Fragen einer Aufklärung: Welches ist die Natur des specifischen Niederschlages? Welche chemischen $\mathrm{Be}-$ standtheile der Bakteriencultur einerseits und des ihr homologen Serums andererseits treten bei der Bildung der specifischen Fällung zusammen?

1 R. Kraus und W. Seng, Ein Beitrag zur Kenntniss des Mechanismus der Agglutination. Wiener klin. Wochenschrift. 1899. Nr. 1. 
Der ersteren Frage ist bis jetzt nur Kraus ${ }^{1}$ nähergetreten. Er filtrirte die erhaltenen specifischen Niederschläge ab und glaubte durch qualitative Analyse sie als eine Verbindung zweier Eiweisskörper ansehen zu können, ron denen der eine die Reaction der Alkali-Albuminate, der andere die der Peptone gab.

Seine diesbezüglichen Untersuchungen können jedoch kaum als erschöpfend und einwandfrei angesehen werden.

Ch. Nicolle ${ }^{2}$ hat die in den Culturen enthaltene, zur specifischen Niederschlagsbildung nothwendige Substanz näher studirt und ihr den nicht ganz glücklich gewählten Namen „substance agglutinée“ gegeben, der besser für den specifischen Niederschlag selbst zu reserviren gewesen wäre. Thatsächlich wird diese Bezeichnung schon von Nicolle selbst promiscue auch für die specifischen Niederschläge in Anwendung gebracht: Geeigneter und präciser wäre deshalb der ebenfalls von Nicolle gebrauchte Ausdruck "substance agglutinable", die er als bei der Agglutination passiv betheiligte Componente der activen ,substance agglutinante" gegenüberstellt.

Nach Nicolle ist die agglutinirbare Substanz ein integrirender Bestandtheil gewisser Bakterienkörper. Von ihrer Gegenwart ist das Phänomen der Agglutination abhängig, indem sie sich mit der agglutinirenden Substanz zu den specifischen Niederschlägen vereinigt. Sie diffundirt aus den Bakterienleibern in die Culturmedien. Thre Bildung ist von der Art und der Reaction der Nährsubstrate nur insoweit abhängig, als diese ein genügendes Wachsthum der Keime ermöglichen.

Gegen Erwärmung ist die agglutinirbare Substanz äusserst resistent. Sie verträgt selbst Temperaturen bis zu $140^{\circ}$. Etwas empfindlicher ist die agglutinirbare Substanz der Typhusbacillen, die durch Temperaturen über $115^{\circ}$ vernichtet wird.

Kälte, Insolation, Austrocknung, die Einwirkung von Antisepticis, wie Formol, Chloroform, Thymol haben keinen Einfluss auf dieselbe. Sie ist löslich in Alkohol absolutus und Aether.

Thre Injection in den Thierkörper hat die Entstehung der agglutinirenden Substanz zur Folge.

Ueber die chemische Natur der agglutinirenden Substanz äussert Nicolle keine Meinung. Doch wïrde aus ihrer Löslichkeit in absolutem Alkohol und Aether, wodurch sie sich nach Nicolle von allen Toxinen

1 Ueber specifische Reactionen in keimfreien Filtraten aus Cholera-, Typhus- u. Pest-Bouillonculturen erzeugt durch homologes Serum. Wiener klin. Wochenschrift. 1897. Nr. 32.

2 Recherches sur la substance aggivitinée p. $\mathrm{Ch}$. Nicoll e. Annales de l'Institut Pasteur. 1898. Nr. 3. p. 161. 
bakteriellen Ursprunges unterscheidet, hervorgehen, dass sie nicht $z u$ den Eiweisskörpern gerechnet werden könne.

Ueber die agglutinirende Substanz im Blute und in den Gewebssäften Typhöser, das sogenannte Typhus-Agglutinin, liegen von verschiedenen, insbesondere französischen Autoren Mittheilungen vor, unter denen namentlich die von Widal und Sicard ${ }^{1}$ Erwähnung verdienen. Von ibren Untersuchungen sind besonders die folgenden von Wichtigkeit.

Filtration schwach agglutinirender Flüssigkeiten (Urin, pericardiales Serum u. s. w.) durch eine Porzellankerze hat ein vollständiges oder theilweises Verschwinden der agglutinirenden Eigenschaft derselben zur Folge.

Sättigung von Serum oder Plasma mit $\mathrm{MgSO}_{4}$ bei Zimmertemperatur fällt mit den Globulinen zugleich das Agglutinin, indem das albuminhaltige Filtrat sich vollständig, oder bei sehr hochwerthigem Serum nur noch in geringem Grade wirksam erweist.

Ebenso gelang es durch Versetzen von Oxalat-Plasma mit Kochsalz im Verhältniss von 15:100 mit dem Fibrinogen einen Theil des Agglutinins auszufällen, indem die Lösung des erhaltenen Niederschlages sich wirksam erwies.

Aus Milch konnte durch Sättigen mit $\mathrm{MgSO}_{+}$ebenso wie aus dem Blute das gesammte Agglutinin zusammen mit dem Caseïn zur Abscheidung gebracht werden. Nur wenn die Milch sehr hochwerthig war, gingen auch in das Filtrat noch Spuren von Agglutinin über. Durch Kochsalzzusatz zur Milch war auch hier immer nur eine geringe Ausfällung erzielbar und das Filtrat blieb stets activ.

Ebenso konnte aus Milch durch Essigsäure im Verhältniss von 1 bis 2:1000 mit dem Caseïn das Agglutinin ausgeschieden werden, indem der gewaschene und dann mit 1 Procent Kochsalz oder Natronlauge gelöste Niederschlag stark agglutinirend wirkte.

Um die Frage zu entscheiden, ob es sich bei der Ausfallung der Agglutinine um eine blosse mechanische Mitreissung handle, wie wir das z. B. bei gewissen Enzymen beobachten, haben Widal und Sicard Blut mit Alkohol gefällt, den Niederschlag durch 8 Tage stehen gelassen, damn im Vacuum über $\mathrm{H}_{2} \mathrm{SO}_{4}$ getrocknet und in Wasser gelöst. Die Lösung war stets wirkungslos.

1 Bulletin de l'academie de médecine, 1896, séance du 29. septembre. Recherches sur la nature de la substance agglntinante et sa fixation sor les albuminoides du sang et des humeurs des typhiques p. M. Dieulafoy en collaboration avec MM. Widal et Sicard und Annales de l'Institut Pasteur, 1897, p. 353. Étude sur le sérodiagnostic et sur la réaction agglutinante chez les typhiques par M. Widal et Sicard. 
Aus den angeführten Ergebnissen ihrer Untersuchungen ziehen Widal und Sicard den Schluss, dass die Agglutinine bezw. das TyphusAgglutinin an verschiedene Eiweisskörper wie die Serum-Globuline, das Fibrinogen oder das Caseïn fest gebunden seien. Sie würden mit denselben aus ihren Lösungen gefallt, ohne dass es sich dabei um ein blosses mechanisches Mitgerissenwerden handle, wie eben die Unwirksamkeit des Alkoholniederschlages beweise. Doch könne die eine agglutinirende Componente zerstört werden, während die andere Eiweiss-Componente erbalten bleibe.

Ehe ich auf eine kritische Betrachtung dieser Anschauuug des Näheren eingehe, will ich die Resultate meiner Studien anführen.

\section{Untersuchungen über das chemische Verhalten des Typhus-Agglutinins.}

Unter dem Typhus-Agglutinin verstehen wir jene specifisch auf die Typhusbacillen bewegungshemmend und agglomerirend wirkende Substanz, die sich im Thierkörper unter dem Einfluss der Bakterien selbst oder ihrer Stoffwechselproducte bildet.

Eine absolute quantitative Bestimmung der in den verschiedenen Gewrebssäften und speciell im Blute vorhandenen Agglutininmenge ist natürlich so lange unmöglich, als es nicht gelingt, diese merkwürdige Substanz rein darzustellen. Dagegen lässt sich ein relatives Maass derselben mit Beziehung auf ihre specifische Wirkung leicht gewinnen. In Analogie zu anderen Werthbestimmungen bakterieller Producte können wir als Agglutinineinheit jene Menge eines beliebigen Agglutinins" bezeichnen, die gerade hinreicht, um eine gleich grosse Menge der homologen Bakteriencultur specifisch zu beeinflussen. Der Verdünnungsgrad, in welchem eine Gewebsflüssigkeit gerade noch agglutinirend wirkt, giebt uns unter dieser Voraussetzung direct die Zahl der vorhandenen Agglutinineinheiten an.

Wenn nun die Werthbestimmung des Agglutinins naturgemäss nur eine relative sein kann, so haftet ihr überdies noch ein zweiter Nachtheil an, indem sie durch subjective Beurtheilung gewonnen wird.

Der bewegungshemmende und Häufchen bildende Einfluss des Agglutinins zeigt stufenweise Verschiedenheiten. Die Bakterien werden je nach der Concentration des Agglutinins bald sofort und rollständig zur Ruhe gebracht und in wenige grosse dichte Haufen geballt, bald bleibt einem grösseren oder kleineren Theile derselben ihre Locomotionsfähigkeit bewahrt, während gleichzeitig die Agglomerate kleiner und lockerer werden, wobei 
innerhalb derselben ziemlich lebhafte Bewegungserscheinungen der einzelnen Keime beobachtet werden.

Die Schwierigkeiten wachsen noch durch den Umstand an, dass namentlich in älteren Typhusculturen nicht selten spontane Häufchenbildung beobachtet wird, welche bei Bestimmung des Grenzwerthes zu Fehlern Veranlassung geben kann.

Dieser allen Untersuchern wohlbekannte Umstand erfordert stets die Anfertigung von Controllpräparaten aus der nativen Cultur. Dagegen ist bis jetzt bei der Werthbestimmung des Agglutinins nicht berücksichtigt worden, dass auch die Anzahl der in der Raumeinheit vorhandenen Keime eine wesentliche Rolle bei derselben spielt. Verdünnt man eine 24 stündige Typhus-Bouilloncultur auf das 2-, 3- oder 5 fache, so wird mit dem Verdünnungsgrade auch der Grenzwerth der Reaction hinausgeschoben. So zeigte, um nur ein Beispiel aus einer Reihe gleichartiger Befunde hervorzuheben, eine unverdünnte Typhuscultur einen Werth von 2200 Agglutinationseinheiten. Mit Bouillon im Verhältniss von 1:3 gemischt, stieg der gemessene Werth auf 3000 und bei weiterer Verdünnung von $1: 6$ bis auf 4300 Aggl.-E.

Diese Thatsache scheint auch bei der bekannten Beobachtung, dass ganz junge Culturen sich zu Agglutinatonsbestimmungen wesentlich besser eignen als ältere, eine wichtige Rolle zu spielen. In diesen ist eben die Anzahl der vorhandenen Keime eine bei weitem geringere. Dass für die feinere Differenzirung auch die gute Isolirung der einzelnen Bakterien, sowie ihre lebhafte Beweglichkeit mit in Frage kommt, ist ohne weiteres zuzugeben. Bei entsprechender Verdünnung selbst 3 bis 4 tägiger Culturen wichen jedoch meine Resultate von denen, die ich bei Anwendung 6 stündiger erhielt, nicht wesentlieh ab, wie folgende Versuche zeigen.

\begin{tabular}{c|c|c}
\hline Alter der Cultur & Verdünnung & $\begin{array}{c}\text { Zahl der } \\
\text { Aggl.-Einheiten }\end{array}$ \\
\hline \hline 6 Stunden & $\emptyset$ & 2100 \\
24 " & $1: 3$ & 1900 \\
48, & $1: 8$ & 2300 \\
$72, "$ & $1: 8$ & 2000
\end{tabular}

Ob die Angabe Pfeiffer's, dass die Virulenz bei den Choleravibrionen für ihre Agglutinationsfähigkeit von Wesenheit sei, auch für die Typhusbacillen Geltung besitzt, dafür haben meine Bestimmungen keine Belege geliefert. 
Dass endlich der Vorgang der Agglutination zu seinem Ablaufe eine gewisse Zeit erfordert, dass die Aussentemperatur Einfluss auf ihn hat und dass die Reaction am feinsten im hängenden Tropfen $\mathbf{z u}$ beobachten ist, sind hinlänglich bekannte Dinge. Ich habe alle diese Verhältnisse nur deshalb so ausführlich discutirt, weil sie für eine quantitative Werthbestimmung von der grössten Bedeutung sind, wenn man übereinstimmende Resultate gewinnen will. Fast würde es scheinèn, dass die Erfüllung einer solchen Menge von Voraussetzungen eine Breite der Fehlergrenzen bedingen müsse, die eine vergleichbare Messung illusoriseh macht. Das ist indessen durchaus nicht der Fall, wenn man bei seinen Untersuchungen immer in derselben Weise verfährt. Ich prüfte stets im hängenden Tropfen gegen 24stündige Typhus-Bouilloncultur. Das Controllpräparat musste vollkommene Isolirung der Keime ergeben. Durch häufiges Umzüchten auf Agar vermeidet man am besten die störende Bildung eines Oberflächenhäutchens. Die verwendete Cultur wird vor dem Gebrauche jedesmal gut durchgeschüttelt, weil sich sonst an der Oberfiäche unverhältnissmässig zahlreiche Keime ansammeln. Als Grenzreaction wählte ich das deutliche Auftreten von Häufchen, auch wenn zwischen und innerhalb derselben noch lebhaft bewegliche Keime zu erkennen waren. War nach 15 Minuten bei Zimmertemperatur eine deutliche Einwirkung nicht zu constatiren, so wurde der Versuch als negativ betrachtet.

\section{Verhalten des Typhus-Agglutinins im Blutserum gegen eiweissfällende Reagentien.}

Das zu den folgenden Versuchen verwendete Serum stammte von einem Pferde, das mit subeutanen Injectionen von abgetödteten Typhusbacillen behandelt" worden war. Sein Werth betrug 2000 Aggl.-E.

\section{a) Fällung durch absoluten Alkohol.}

I. Versuch. $5^{\mathrm{cem}}$ Serum $+5^{\mathrm{ccm}}$ Alkohol absolutus. Der Niedersohlag sofort in der gleichen Menge destillirten Wassers, dem einige Tropfen 20 proc. $\mathrm{Na}_{2} \mathrm{CO}_{3}$ zugesetzt werden, gelöst. Die Lösung ist klar und zeigt 900 Aggl.-E. Das leicht getrübte Filtrat enthält 350 Aggl.-E.

II. Versuch. $5^{\mathrm{com}}$ Serum $+10^{\mathrm{cm}}$ Alkohol. absol. Das klare Filtrat agglutinirt nur in Concentrationen, wie sie dem Alkoholgehalte als solchem entsprechen.

Der Niederschlag wird sofort mit 15 eem destillirtem Wasser digerirt. Er löst sich nicht vollständig. Die opalescirende filtrirte Lösung enthält 900 Aggl.-E.

III. Versuch. $5^{\mathrm{cm}}$ Serum $+10^{\mathrm{cm}}$ Alkohol absol. durch 8 Tage unter Lichtabschluss stehen gelassen. Hierauf filtrirt. 
Das klare Filtrat zeigt unverdünnt schwache Agglutination und ist im Verhältniss von $1: 2$ ganz wirkungslos.

Der Niederschlag wird mit $25^{\mathrm{cm}}$ destillirtem Wasser 48 Stunden stehen gelassen. Es erfolgt keine Lösung, sondern nur starke Quellung desselben. Die trübe gequollene Flüssigkeit geht zum Theil durch ein Filter und enthält 50 Aggl.-E. Der Rückstand abermals mit $25 \mathrm{ccm}$ Wasser durch $3 \times 24$ Stunden behandelt, giebt noch 35 Aggl.-E.

IV. Versuch. $5^{\mathrm{cm}}$ Serum $+10^{\mathrm{cm}}$ Alkohol absol. im Vacuum über $\mathrm{H}_{2} \mathrm{SO}_{4}$ bei Zimmertemperatur getrocknet. Nach 14 Tagen in leicht alkalischem Wasser verrührt. Der Rückstand geht dabei nur in geringem Maasse in Lösung und hat sein Agglutinationsvermögen vollständig eingebüsst.

Diese wiederholt angestellten Experimente zeigen, dass das TyphusAgglutinin durch genügende Alkoholmengen zusammen mit den übrigen Eiweisskörpern des Blutserums vollständig ausgefällt wird. Das alkoholische Filtrat bleibt nur dann wirksam, wenn die zur Fällung verwendete Alkoholmenge zur Coagulation des Eiweisses nicht ausreicht. Der Alkohol besitzt aber auch nach kurzer Einwirkung gegenüber dem Typhus-Agglutinin eine zerstörende Kraft, welche mit seiner denaturirenden Eigenschaft den Eiweisskörpern gegenüber leicht in eine gewisse Paralelle gebracht werden kann. Vor einer vollständigen Vernichtung wird das Agglutinin wahrscheinlich dadurch geschützt, dass die Coagula rom Alkohol nicht völlig durchdrungen werden. Durch Trocknen des alkoholischen Niederschlages über $\mathrm{H}_{2} \mathrm{SO}_{4}$ büsst derselbe indessen seine Activität vollständig ein.

Die letztere auch von Widal und Sicard gefundene Thatsache hat dieselben zu der Anschauung bestimmt, dass das Typhus-Agglutinin von ausfallenden Eiweisskörpern nicht bloss mechanisch nach Art der Diastasen mitgerissen werde. Auch ich bin auf Grund anderer später zu erwähnender Thatsachen zu diesem Schlusse gelangt, ohne jedoch zugeben zu können, dass die genannten Autoren durch ihre Versuchsführung zu dieser Folgerung berechtigt waren. Denn indem dieselben annehmen, dass es sich um eine directe Fixation des Agglutinins an die Eiweisskörper handle, mussten sie consequenter Weise das Verschwinden desselben durch Alkoholfällung ebenfalls einer Zerstörung durch diesen zuschreiben. Wie aber soll man unterscheiden, ob eine nur mechanisch mitgerissene oder eine an den Niederschlag organisch gebundene Substanz vernichtet worden ist?

Wird das durch Alkohol gewonnene Präcipitat genügend rasch von demselben befreit, so behält dasselbe durch lange Zeit seine Activität.

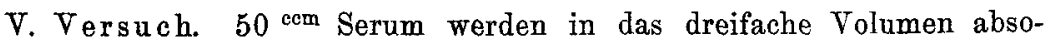
luten Alkohols eingeträufelt. Der entstandene Niederschlag wird sofort durch Absaugen rom Alkohol möglichst befreit, sodann mit Aether nachgewaschen und getrocknet. Hierauf wird er im evacuirten Exsicator über Schwefel- 
säure bis zur Gewichtsconstanz belassen. Durch Zerstossen des so erhaltenen Niederschlages gewinnt man ein feines gelbliches Pulver, das in physiologischer $\mathrm{NaCl-Lösung} \mathrm{bis} \mathrm{auf} \mathrm{einzelne} \mathrm{Partikelchen} \mathrm{löslich} \mathrm{ist.} 0 \cdot 1 \mathrm{grm}$ des Pulvers geben mit $1440 \mathrm{cem}$ Wasser digerirt noch deutliche Agglutination, demnach besitzt das Pulver eine Werthigkeit von 14400 Aggl.-E. Eine abermalige Prüfung nach 3 und nach 6 Monaten lässt keine Abnahme der Wirksamkeit erkennen.

\section{b) Fällungsversuche mit verschiedenen Salzen.}

\section{Mit Magnesiumsulfat.}

I. Versuch. 5 com Serum werden mit $\mathrm{MgSO}_{4}$ in Substanz im Ueberschuss versetzt und durch 48 Stunden bei Zimmertemperatur unter offterem Umrühren belassen. Hierauf wird der Niederschlag abfiltrirt und mit $5 \mathrm{~cm}$ gesättigter $\mathrm{MgSO}_{4}$-Lösung nachgewaschen. Das klare Filtrat agglutinirt nur in ganz geringem Grade. Bei einer Verdünnung von 1:10 ist die Reaction bereits völlig negativ. Der Niederschlag, in $25^{\mathrm{cm}}$ Wasser gelöst, enthält 1600 Aggl.-E.

II. Versuch. 5 cem Serum mit $\mathrm{MgSO}_{4}$ in Substanz durch 24 Stunden bei $37^{\circ}$ stehen gelassen. Nach dieser Zeit ist das klare Filtrat bis auf Immobilisirung der Bakterien wirkungslos. Der in $10^{\mathrm{cm}}$ physiol. NaCl-Lösung aufgenommene Niederschlag giebt 1800 Aggl.-E.

Es gelingt demnach, durch $\mathrm{MgSO}_{4}$ die Typhus-Agglutinine auszusalzen, wie dies auch schon Widal und Sicard gefunden haben. Dabei erleidet man jedoch stets grössere oder kleinere Verluste an wirksamer Substanz, deren Ursache nicht festgestellt werden konnte. Ein ähnliches Verhalten zeigen nach Untersuchungen von Pfeiffer und Proskauer ${ }^{1}$ auch die Cholera-Antikörper.

Ebenso wie aus dem Blutserum konnten Widal und Sicard aus der activen Milch das Typhus-Agglutinin durch Aussalzen mit $\mathrm{MgSO}_{4}$ abscheiden. Sie schliessen daraus, dass das Typhus-Agglutinin nicht nur an die Globuline des Blutserums, sondern auch an andere Eiweisskörper, wie das Caseïn fixirt sei, ohne der Möglichkeit Rechnung zu tragen, dass das Agglutinin nicht nur mit den in Frage kommenden Eiweisskörpern, sondern auch neben denselben unter dem Einfluss von $\mathrm{MgSO}_{4}$ abgeschieden werden könne. Allerdings konnten sie aus sehr hochwerthigem Serum die Agglutinine durch $\mathrm{MgSO}_{4}$ nicht vollständig ausfällen und zwar deshalb, weil, wie sie ganz richtig vermuthen, Spuren desselben das Filter passiren. Dass aber die Filtrate trotz wiederholter Präcipitation mit $\mathrm{MgSO}_{4}$ immer noch wirksam blieben, findet seine Erklärung darin, dass die geringe Niederschlagsbildung zum Verschluss der Poren des Filters nicht ausreicht.

${ }^{1}$ R. Pfeiffer u. B. Proskauer, Beiträge zur Kenntniss der specifisch wirksamen Körper im Blutserum von cholera-immunen Thieren. Centralblatt für Bakteriologie. Bd. XIX. S. 191. 
Schickt man derartige Filtrate von nur geringer Activität nach Sättigung derselben mit $\mathrm{MgSO}_{4}$ über Filter, auf denen unmittelbar vorher der ebenso gewonnene Globulinniederschlag aus normalem Serum zurückgehalten wurde, so ist die ablaufende Flüssigkeit frei von wirksamer Substanz.

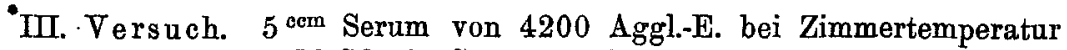
durch 24 Stunden mit $\mathrm{MgSO}_{4}$ in Substanz übersättigt.

Niederschlag, in $20^{\mathrm{cem}}$ physiol. Kochsalzlösung digerirt, enthält auf das ursprüngliche Volumen berechnet, 3800 Aggl.-E., das Filtrat 30 Aggl.-E. Letzteres abermals in der gleichen Weise mit $\mathrm{MgSO}_{4}$ behandelt und durch ein Filter gesandt, auf welchem zuvor der Globulinniederschlag eines Pferdeserums von der Agglutinationsfähigkeit 0 aufgefangen wurde, ist nunmehr wirkungslos.

\section{Fällung des Typhus-Agglutinins durch Ammoniumsulfat.}

I. Versuch. 5 ccm Serum mit $\left(\mathrm{NH}_{4}\right)_{2} \mathrm{SO}_{4}$ in Substanz bei Zimmertemperatur im Ueberschuss versetzt und durch 24 Stunden stehen gelassen.

Filtrat zeigt nur geringe Activität, eine dreifache Verdünnung ist bereits völlig unwirksam. Niederschlag enthält 1650 Aggl.-E. versetzt.

II. Versuch. $5^{\mathrm{com}}$ Serum mit $5^{\mathrm{ccm}}$ gesättigter Ammonsulfatlösung

Das Filtrat enthält 10, der Niederschlag 1850 Aggl.-E. versetzt.

III. Versuch. $5^{\mathrm{ccm}}$ Serum mit $4^{\mathrm{cmm}}$ gesättigter Ammonsulfatlösung

Das Filtrat enthält 135 Aggl.-E., der Niederschlag 1860.

IV. Versuch. $5^{\mathrm{com}}$ Serum mit $3^{\mathrm{ccm}}$ concentrirter Ammonsulfatlösung versetzt.

Das Filtrat enthält 400, der Niederschlag 1470 Aggl.-E.

Diese Experimente lehren, dass das Typhus-Agglutinin durch Ammonsulfat nicht nur bei vollständiger Sättigung, sondern auch in halb gesättigter Lösung quantitativ ausgefallt wird. Bei geringerer Concentration bleibt auch das Filtrat in rascher Progression wirksam. Die halb gesättigte Ammonsulfatlösung ist in ihrem Verhalten der ganz gesättigten $\mathrm{MgSO}_{4}$ Lösung durchaus analog. Es besteht also in dieser Beziehung eine vollständige Parallele zwischen dem Typhyus-Agglutinin einerseits und den Globulinen andererseits, die aus ihren Lösungen ebenfalls noch durch halb gesättigtes Ammonsulfat vollständig aussalzbar sind.

\section{Verhalten des Typhus-Agglutinins gegen Chlornatrium.}

$5 \mathrm{~cm}$ Serum mit $\mathrm{NaCl}$ in Substanz übersättigt und durch 24 Stunden bei $37^{\circ}$ stehen gelassen. Es entsteht ein sehr geringer Niederschlag, der mit bei $37^{\circ}$ gesättigter Kochsalzlösung bei derselben Temperatur nachgewaschen und sodann durch Wasserzusatz gelöst wird. Sein Agglutinationswerth beträgt 250, der des ursprünglichen Filtrates 2000 Einheiten. 


\section{Verhalten des Typhus-Agglutinins gegen Fällung mit Natriumsulfat.}

1. Versuch. In $5^{\mathrm{cm}}$ Serum werden bei Zimmertemperatur Krystalle von $\mathrm{Na}_{2} \mathrm{SO}_{4}$ im Ueberschuss eingetragen. Nach 24 Stunden hat sich ein mässig reichlicher Niederschlag gebildet, der mit conc. $\mathrm{Na}_{2} \mathrm{SO}_{4}$ nachgewaschen und sodann auf seine Werthigkeit geprüft wird. Dieselbe beträgt 300, die des Filtrates 1800 Aggl.-E.

II. Versuch. Es wird genau so wie im I. Versuch verfahren, nur werden alle Operationen bei Brüttemperatur $\left(37^{\circ}\right)$ vorgenommen.

Der Niederschlag ist diesmal viel reichlicher und hat fast das gesammte Agglutinin zurückgehalten.

Niederschlag 2050, Filtrat 25 Aggl.-E.

\section{Verhalten des Typhus-Agglutinins gegen Fällung mit Natrium nitricum.}

$5^{\mathrm{cm}}$ Serum mit $\mathrm{NaNO}_{3}$ in Substanz bei $37^{\circ}$ durch 24 Stunden stehen gelassen. Der Niederschlag bei derselben Temperatur mit conc. $\mathrm{NaNO}_{3}$ gewaschen und in $15 \mathrm{~cm}$ Wasser gelöst, giebt 1100, das Filtrat und Waschwasser 1000 Aggl.-E.

\section{Verhalten des Typhus-Agglutinins gegen Fällung mit Natrium aceticum.}

$5^{\mathrm{ccm}}$ Serum werden bei $37^{\circ}$ mit essigsaurem Natrium in Substanz im Ueberschuss versetzt und 24 Stunden stehen gelassen. Der ziemlich reichliche Niederschlag wird abfiltrirt und mit conc. Lösung von Natriumacetat in der Wärme nachgewaschen. In Wasser gelöst beträgt sein Agglutinationswerth 600, der des Filtratet zusammen mit dem Waschwasser 700 Einheiten. Es hat demnach ein erheblicher Verlust an wirksamer Substanz stattgefunden.

7) Verhalten des Typhus-Agglutinins gegen Kalium aceticum. $5^{\mathrm{cem}}$ des Serums werden mit Kaliumacetat in Substanz bei $37^{\circ}$ durch 24 Stunden im Ueberschuss versetzt und stehen gelassen.

Nach dieser Zeit misst das klare Filtrat 7 Aggl.-E. Der Niederschlag löst sich in destillirtem Wasser nicht mehr vollständig auf und hat seine Wirksamkeit bis auf 80 Einheiten verloren.

Eine concentrirte Lösung von Kalium aceticum zeigt bis zu einer Verdünnung von 1:5 typische Agglutination, welche von der specifischen nicht zu unterscheiden ist.

Von den untersuchten Salzen hat das essigsaure Kalium gegenüber dem Typhus-Agglutinin die grösste zerstörende Kraft.

8. Verhalten des Typhus-Agglutinins gegen Kaliumchlorid. $5^{\mathrm{ccm}}$ Serum durch 24 Stunden mit $\mathrm{KCl}$ bei $37^{\circ}$ im Ueberschuss versetzt.

Der geringe Niederschlag unter denselben Bedingungen wie in den vorangehenden Versuchen behandelt, enthält 50 Aggl.-E., während das Filtrat 2000 derselben messen lässt. 
Die zu den geschilderten Experimenten gewählten Salze sind dieselben, deren Fällungskraft gegenüber den Globulinen aus einer Arbeit von S. Lewith ${ }^{1}$ genauer bekannt ist. Auch die Versuchsanordnung ist mit der von Lewith insoweit vergleichbar, als die Salzsättigung ebenfalls bei einer Temperatur von $37^{\circ}$ vorgenomen wurde. Berücksichtigt wurde nur die durch Sättigen mit gepulvertem Salz im Maximum erreichbare Wirkung, um zunächst einen Vergleich in gröberen Umrissen gewinnen zu können.

Dass die Albumine des Blutserums zu dem Agglutinin des Typhus in keiner engeren Beziehung stehen, haben schon Widal und Sicard auf Grund ihrer Versuche richtig hervorgehoben. Die folgende Tabelle enthält eine übersichtliche Zusammenstellung des Verhaltens der Globuline des Blutserums einerseits und des Typhus-Agglutinins andererseits gegenüber einer Reihe von Salzen, die oben im Einzelnen angeführt wurden.

\begin{tabular}{|c|c|c|}
\hline $\begin{array}{l}\text { Verwendetes } \\
\text { Salz }\end{array}$ & \multicolumn{2}{|c|}{$\begin{array}{l}\text { Durch Sättigung mit gepulvertem Salz ist erreichbar gegenüber } \\
\text { den Eiweisskörpern }\end{array}$} \\
\hline Natriumsulfat & Unvollständ. Globulinausfällnng & $\begin{array}{c}\text { Fast vollständige Fällung des } \\
\text { Typhus-Agglutinin }\end{array}$ \\
\hline Ammonsulfat & $\begin{array}{c}\text { Vollständige Ausfällung beider } \\
\text { Eiweisskörper }\end{array}$ & $\begin{array}{l}\text { Vollständige Fällung (schon in } \\
\text { halb gesättigter Lossung). }\end{array}$ \\
\hline Natriumacetat . & Globulinausfälling bis auf Spuren & Unvollständige Fällung. \\
\hline Magnesiumsulfat & Vollständige Globulinausfällung & Vollständ. Fällung bis auf Spuren. \\
\hline Kaliumacetat. . & $\begin{array}{c}\text { Vollständige Ausfällung } \\
\text { der Eiweisskörper }\end{array}$ & Zerstörung des Agglutinins. \\
\hline Natriumchlorid & Unvollständ. Globulinausfällung & Geringe Fällung. \\
\hline Kaliumchlorid & & \\
\hline Natriumnitrat & $\begin{array}{l}\text { Nahezu vollständige Globulin- } \\
\text { ausfällung }\end{array}$ & Unvollständige Fällung. \\
\hline
\end{tabular}

Im Grossen Ganzen ergiebt sich demnach zwischen den Globulinen und dem Typhus-Agglutinin eine gute qualitative Uebereinstimmung in ihrer Aussalzbarkeit durch die genannten Salze, wenn auch im Einzelnen grössere und kleinere quantitative Differenzen bestehen. Am auffallentsten ist der Unterschied gegenüber dem Natriumnitrat, wo einer fast vollständigen Globulinfällung eine etwa 50 procentige Agglutininfällung entgegensteht.

Wir werden also das Typhus-Agglutinin vor Allem mit den Serumglobulinen nicht identificiren können, wir werden ebenso nicht annehmen können, dass es in Gestalt einer Seitenkette dem Serumglobulin in toto

IS. Lewith, Zur Lehre von der Wirkung der Salze. I. Mittheilung. Das Verhalten der Eiweisskörper des Blutserums gegen Salze. Archiv für experimentelle Pathologie u. Pharmakologie. Bd. XXIV. S. 1.

Zeitschr. f. Hygiene. XXXII. 
anhänge. Wir werden aber auch seinen Globulincharakter nicht ohne Weiteres in Abrede stellen und das umsoweniger, als wir ja immer mehr zu der Ansicht geführt werden, dass der von uns als Serumglobulin bezeichnete Körper kein chemisches Einzelindividuum darstellt, sondern vielmehr eine Gruppe einander sehr nahe stehender Eiweissverbindungen zusammenfasst.

Die theilweise, ja beinahe vollständige Zerstörung, welche das TyphusAgglutinin sowohl unter der Einwirkung des Alkohols als auch unter der gewisser Salze, wie namentlich des Kaliumacetats, unterliegt, dürfte dem Vorgange der Denaturirung sehr nahe stehen, dem die nativen Eiweisskörper unter dem Einfluss derselben Agentien ausgesetzt wird. Die diesbezüglichen Salzwirkungen sind allerdings im Detail wenig gekannt, aber gerade das Beispiel des Kaliumacetats weist auf einen solchen Zusammenhang direct hin, indem auch der betreffende Eiweissniederschlag unter dem Einfluss dieses Salzes unlöslich wird. Wenn nun unter den gleichen Verhältnissen auch das Agglutinin seine Activität verliert, wem wird das wunderbar erscheinen?

Corpora non agunt nisi fluida! Dem Unlöslichwerden eutspricht gewiss auch eine Aenderung im molekularen Gefüge, wofür uns in dem Verluste der Wirksamkeit ein sichtbarer Ausdruck entstehen mag.

9. Verhalten des Typhus-Agglutinins gegenüber den Salzen der Schwermetalle.

Untersucht wurden von diesen das $\mathrm{CuSO}_{4}$ und $\mathrm{ZnCl}$, beide in 2 proc. Lösung. In dieser Concentration bewirken sowohl das Chlorzink als auch das Kupfersulfat Agglutination der Typhusbacillen, die jedoch bald ihre Grenze erreicht. Verdünnungen von 1:10 sind bereits vollständig unwirksam.

a) Fällung mit CuSO,

I. Versuch. $5^{\mathrm{ccm}}$ Serum mit $2.5^{\mathrm{cm}} 2$ proc. $\mathrm{CuSO}_{4}$ duroh 6 Stunden stehen gelassen.

Das Filter enthält 150, der Niederschlag 800 Aggl.-E.

II. Versuch. $5^{\mathrm{cm}}$ Serum mit $5^{\mathrm{cm}} 2$ proc. $\mathrm{CuSO}_{4}$ durch 6 Stunden bei Zimmertemperatur stehen gelassen.

Das Filter enthält 250, der Niederschlag 700 Aggl.-E.

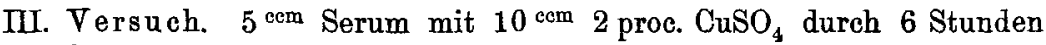
steben gelassen.

Das Filtrat enthält 600, der Niederschlag 50 Aggl.-E. 


\section{b) Fällung mit ZnCl.} lassen.

$5^{\mathrm{cm}}$ Serum mit $5 \mathrm{~cm} 2$ proc. Chlorzink durch 24 Stunden stehen ge-

Das Filter enthält 50, der Niederschlag 1200 Aggl.-E.

Das Typhus-Agglutinin wird demnach auch durch die Salze der Schwermetalle aus seinen Lösungen gefällt und ist, wie dies namentlich die Versuche mit $\mathrm{CuSO}_{4}$ zeigen, im Ueberschuss des Fällungsmittels wieder Iöslich. Auch die Salze der Schwermetalle haben eine zerstörende Kraft gegenüber dem Typhus-Agglutinin, indem die Summe des Werthes von Filtrat und Niederschlag nicht mehr die Höhe der ursprünglich vorhandenen 2000 Aggl.-E. erreicht.

\section{c) Wirkung von Säuren auf das Typhus-Agglutinin.}

\section{Versuche mit Salzsäure.}

Ein gleichbleibendes Quantum von Typhusserum wurde mit verschiedenen Mengen von $1 / 10$ normal $\mathrm{HCl}$ solange versetzt, bis in der letzten Probe deutlich freie Salzsäure nachweisbar war.

Die Werthbestimmung nach wenigen Minuten bis nach 24 Stunden ergab jedesmal bei Gegenwart freier Säure eine erhebliche Verminderung oder ein rölliges Verschwinden der Agglutinationsfähigkeit je nach der Menge der zugesetzten Säure und der Dauer ihrer Einwirkung.

4 Eprouvetten wurden in folgender Weise beschickt, sodann zugeschmolzen und 24 Stunden bei $37^{\circ}$ stehen gelassen.

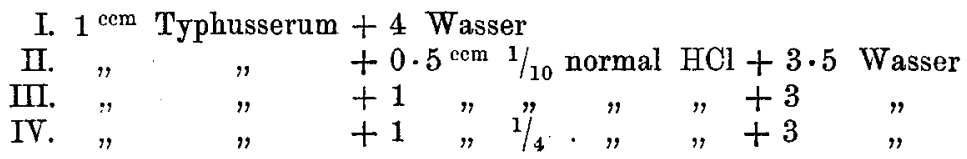

Die Bestimmung ergab sodann für das Controll-Röhrchen I 350 Aggl.-E., für II 300, für III 10 und für IV 5 Aggl.-E.

Bei geringem Säureüberschuss kann durch Neutralisation mit $\mathrm{NaOH}$ eine theilweise Restitution des Agglutinins erzielt werden, wenn erstere bald darauf vorgenommen wird.

Wie die Salzsäure verhalten sich auch andere Mineralsäuren, z. B. Schwefel- oder Salpetersäure.

Von den organischen Säuren wurde nur die Essigsäure untersucht.

Bis zu eben noch saurer Reaction dem Serum zugesetzt, bleibt die Essigsäure ohne wesentlichen Einfluss auf die agglutinirende Kraft desselben, sie setzt letztere aber wesentlich herab oder vernichtet sie endlich völlig, wenn sie im Ueberschuss zugefügt wird. 


\section{d) Wirkung von Laugen auf das Typhus-Agglutinin.}

Natron- oder Kalilauge mit activem Serum in Verbindung gebracht, hat im Allgemeinen dieselbe schädigende Wirkung auf das Typhus-Agglutinin, wie die Sâuren. Um ein Weniges scheint allerdings die Empfindlichkeit diesen gegenüber geringer zu sein.

4 Röhrchen, die mit demselben Serum wie im vorangehenden Versuche beschickt, sodann zugeschmolzen und durch 24 Stunden bei $37^{\circ}$. belassen wurden, zeigten folgende Werthe:

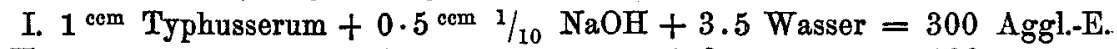

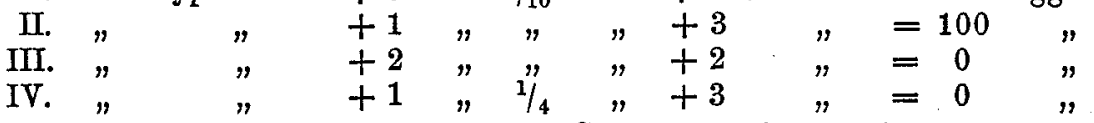

Auch Salze von stark basischem Charakter, wie das Natriumcarbonat, setzen die Agglutinationsfähigkeit herab oder vernichten sie völlig.

e) Wirkung der Verdauungsfermente auf das Typhus-Agglutinin.

\section{Verhalten gegen Pepsin.}

Nachdem wir erfahren haben, dass freie Säure für sich allein im Stande ist, das Typhus-Agglutinin mehr oder weniger zu schädigen, so mussten die Versuche so ausgeführt werden, dass Proben activen Serums einerseits nur der Einwirkung von Säure allein, andererseits ron Säure und Pepsin zugleich unter sonst identischen Bedingungen ausgesetzt wurden. Die gewählten Concentrationen der Sāure lagen zwischen Werthen, welche so klein waren, um das Agglutinin nicht gänzlich zu zerstören, aber doch ausreichten, um eine Wirksamkeit des Pepsins zu ermöglichen. Vorrersuche ergaben, dass die gesuchte Säureconcentration zwischen $\mathbf{0 . 5}$ und $1 \mathrm{ccm} 1 / 10$ normal $\mathrm{HCl}$ auf $1 \mathrm{com}$ Typhusserum von dem Werthe von 1500 Einheiten gelegen war, wobei das genannte Serum durch eine $\mathbf{5}$ fache Verdünnung auf 300 Einheiten reducirt war.

Das Pepsin ebenso wie die später verwendeten Trypsin- und Papayotinpräparate waren von Merck bezogen, wurden in Substanz zugesetzt unỏ hatten sich als gut wirksam gezeigt. Alle Versuche wurden in Eprouretten ausgeführt, die nach ihrer Beschickung zugeschmolzen und durch 24 Stunden bei $37^{\circ}$ belassen worden waren. Nach dieser Zeit hatten Röhrchen:

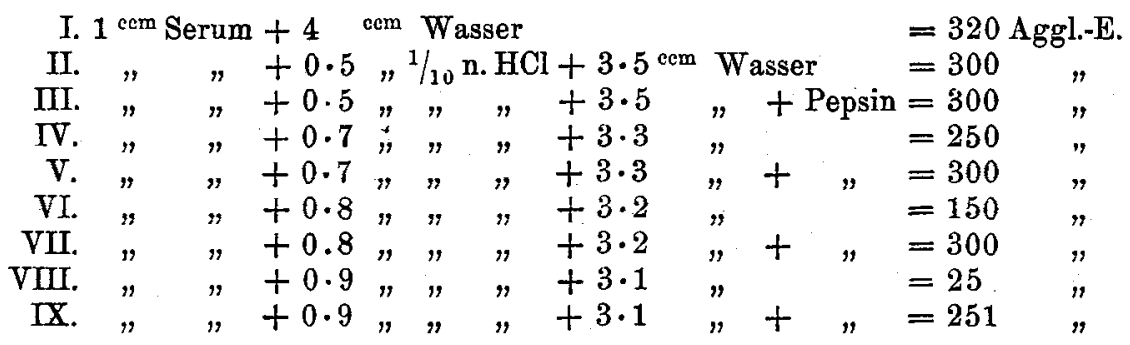


Aus diesen Experimenten geht demnach die Thatsache hervor, dass das Pepsin nicht nur ausser Stande ist, das Typhus-Agglutinin anzugreifen, sondern sogar befähigt erscheint, dasselbe bis zu einem gewissen Grade vor der zerstörenden Einwirkung der Salzsäure zu bewahren.

Der letztere Umstand ist möglicher Weise darauf zurückzuführen, dass das Pepsin einen Theil der Säure für sich in Anspruch nimmt. Der Probe III wurde eine, V zwei, VII drei und IX vier Messerspitzen Pepsin zugesetzt. V, VII und IX waren nach Vollendung des Versuches im Stande, in weiteren 18 Stunden eine Fibrinflocke aufzulösen, in III wurde nur eine starke Auflockerung und ein theilweiser Zerfall derselben beobachtet.

\section{Verhalten gegen Trypsin.}

Die Versuchsanordnung war dieselbe wie bei der Prüfung gegen Pepsin. Der zur Verdauung nothwendige Alkalitätsgrad des Serums wurde durch Hinzufügen entsprechender Mengen von $1 / 10$ normal $\mathrm{NaOH}$ oder von $\mathrm{Na}_{2} \mathrm{CO}_{3}$ erzielt und mittels eingetragener Fibrinflocken controllirt.

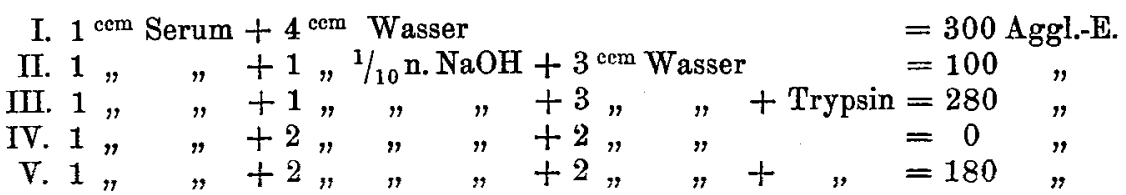

Aehnlich wie das Pepsin vermag also auch das Trypsin das Agglutinin gegen die Zerstörung durch Natronlauge zu schützen. Das Agglutinin zu verdauen ist es jedoch nicht im Stande, auch wenn statt der $\mathrm{NaOH}$ eine 0.4 bis 1 proc. $\mathrm{Na}_{2} \mathrm{CO}_{3}$ Lösung verwendet wird.

\section{Verhalten gegen Papayotin.}

Bezūglich des Papayotin gelten in allen Details die hinsichtlich des Trypsin gemachten Angaben. Trotzdem auf Grund der angeführten Experimente die Behauptung gerechtfertigt ist, dass das Typhus Agglutinin der Verdauung weder durch thierische Fermente, wie Pepsin und Trypsin, noch der durch pflanzliche, wie des Papayotin, unterliegt, konnte dennoch eine Trennung des Agglutinins von den übrigen Eiweisskörpern durch nachträgliche Dialyse der Verdauungsproducte nicht durchgeführt werden.

Es stellte sich nämlich heraus, dass auch das coagulirbare Eiweiss des Blutserums nur äusserst schwer vollständig verdaulich ist, dass aber innerhalb der anwendbaren Aciditäts- bezw. Alkalinitätsgrenzen stets beträchtliche Mengen noch coagulirbaren Eiweisses erübrigten, auch wenn ein grösserer Theil desselben verdaut wordenwar, $d$. h. seine Coagulationsfähigkeit verloren hatte. 
Das gleiche Resultat hatten Controllversuche, die an normalen PferdeBlutserum angestellt wurden. Diese Ergebnisse stehen in Uebereinstimmung mit den Angaben anderer Autoren über die Schwerverdaulichkeit der Eiweisskörper des Blutserums, die sogar zur Annahme einer antienzymischen Kraft des letzteren geführt hat. So fand $\mathrm{Fermi}{ }^{1}$, dass frisches normales Blutserum im Stande sei, Enzyme (Trypsin) unwirksam zu machen.

Kann nun die Thatsache, dass das Thyphus-Agglutinin ron den Verdauungsfermenten nicht angegriffen wird, von den genannten Verhältnissen abgesehen, als absoluter Beweis gegen die Eiweissnatur desselben angesehen werden? Wir kennen auch andere Proteïnsubstanzen, wie das Chondrin, Spongin, Mucin, Fibroin, die Nucleïne, welche der Verdauung nicht unterliegen und können deshalb einen so weitgehenden Schluss auf Grund dieses Umstandes nicht ziehen.

Auch die Blutkörperchen agglutinirenden Eiweisse zeigen nach Untersuchungen von Elfstrand ${ }^{2}$ eine ähnlich grosse Empfindlichkeit gegen Säuren und Alkali, die eine sichere Entscheidung bezüglich ihrer Digestionsähigkeit unmöglich macht.

\section{f) Wirkung von Bakterien auf das Typhus-Agglutinin.}

Schon durch Beobachtungen französischer Autoren, wie durch Widal und Sicard, wissen wir, dass das Typhus-Agglutinin selbst durch reichliches Bakterienwachsthum und lang andauernde Fäulnissprocesse in seiner Wirksamkeit nicht beeinträchtigt wird. Mit Rücksicht auf die Fähigkeit mancher Bakterien kräftige proteolytische Enzyme zu produciren, wurde eine neuerliche Versuchsreihe in folgender Weise ausgeführt. TyphusSerum ron bekanntem Agglutiningehalt wurcle mit Bouillon rerdünnt, in gleicher Menge in Eprouvetten gebracht, mit verschiedenen Bakterien geimpft, sodann die Röhrchen, um eine ungleichmässige Verdunstung zu verhüten, abgeschmolzen und nun durch 14 Tage im Brutofen gchalten. Ueberall war reichliches Wachsthum erfolgt. Hatte sich ein stärkerer Bodensatz oder ein Oberflächenhäutchen gebildet, so wurde so lange geschüttelt, bis eine ziemlich gleichmässige Trübung vorhanden war und dann der Agglutinationswerth bestimmt. Die Resultate dieses Versuches enthält folgende Tabelle.

1 Fermi, Ueber die antienzymische Wirkung des Blutserums. Centralblatt für Bakteriologie. Bd. XXII. S. 1.

${ }^{2}$ Elfstrand, Ueber Blutkörperchen agglutinirende Eiweisse. Görbersdorfer Veröffentlichungen. 1898. S. 1. 


\begin{tabular}{|c|c|c|c|}
\hline \multirow{2}{*}{$\begin{array}{l}\text { Zusammensetzung } \\
\text { der Culturflüssigkeit }\end{array}$} & \multirow[b]{2}{*}{ Geimpft mit } & \multicolumn{2}{|c|}{ Agglutininwerth } \\
\hline & & $\begin{array}{l}\text { vor dem } \\
\text { Versuch }\end{array}$ & $\begin{array}{l}\text { nach dem } \\
\text { Versuch }\end{array}$ \\
\hline $\begin{array}{c}1 \mathrm{cem} \text { Serum + } 5 \text { cem Bonillon } \\
" \\
" \\
" \\
" \\
" \\
" \\
" \\
" \\
"\end{array}$ & $\begin{array}{c}ø \\
\text { Typhus } \\
\text { Cholera } \\
\text { Milzbrand } \\
\text { Staphylococcus aureus } \\
\text { Pyocyaneus } \\
\text { Coli } \\
\text { Diphtherie } \\
\text { Danubicus } \\
\text { Fäulnissbalkterien } \\
\text { Mäusetyphus }\end{array}$ & $\begin{array}{l}1800 \\
1780 \\
1790 \\
1810 \\
1820 \\
1795 \\
1805 \\
1785 \\
1810 \\
1820 \\
1790\end{array}$ & $\begin{array}{l}1850 \\
1760 \\
1820 \\
1800 \\
1790 \\
1800 \\
1815 \\
1785 \\
1800 \\
1825 \\
1810\end{array}$ \\
\hline
\end{tabular}

Die Agglutinationswerthe sind mit Rücksicht auf die gesetzte Verdünnung berechnet. Sie haben durch das Wachsthum der verschiedenen Bakterienarten keine wesentliche Vẹränderung erlitten, indem die Abweichungen am Ende des Versuches sich innerhalb der Fehlergrenzen der Methode bewegen.

\section{g) Verhalten des Typhus-Agglutinins gegen die Dialyse.}

Durch eine Reihe französischer Autoren (Widal-Achard et Bensande) wurde gefunden, dass das Typhus-Agglutinin im Allgemeinen sich als eine nicht dialysirbare Substanz erweist. Es wird aber auch wenigstens theilweise beim Filtriren durch eine $\mathrm{Chamberland-Kerze} \mathrm{zurücligehalten.}$ Mit diesen Angaben stehen auch meine Befunde in vollständiger Uevereinstimmung. Eine selbst durch Monate fortgesetzte Dialyse in Pergamentschlāuchen zuerst gegen strömendes, dann gegen destillirtes Wasser hatte bei Berücksichtigung der eingetretenen Verdünnung einen Verlust ron nicht mehr als 10 bis 15 Procent zur Folge. Es verhält sich demnach das Typhus-Agglutinin im Allgemeinen so wie andere colloide Substanzen. Der Dialyse wurde nicht nur das Blutserum als solches, sondern auch die durch Fällung mit Maguesium- und Ammonsulfat erhaltenen Niederschläge unterworfen. Auch im letzteren Falle hielt sich der Verlust an wirksamer Substanz in den genannten Grenzen. Die Dialyse wurde stets bis zur vollständigen Salzfreiheit fortgesetzt. Trotzdem blieb der grösste Theil der Globuline und mit ihnen auch das Agglutinin in Lösung. Nur eine ganz geringe Niederschlagsmenge, konnte abfiltrirt werden, die mach Waschung mit destillirtem Wasser und Aufnahme in physiologischer Kochsalzlösung immer eine, wenn auch nur ganz geringe Activität besass. 
Ob der Umstand, dass die Globuline noch bei vollständiger Salzfreiheit in Lösung blieben, mit den specifischen Eigenschaften des Typhusserums in einem causalen Zusammenhang stehe, konnte nicht entschieden werden. Aus dem Dialysat konnte mittels Magnesium oder Ammonsulfat das gesammte Agglutinin stets wieder ausgefällt werden. Gegen die Einwirkung von Alkohol, Säuren und Basen war das von den Albuminen durch Mlagnesiumsulfat befreite und dialysirte Agglutinin etwas empfindlicher. Gegen die Verdauungsenzyme verhielt es sich in der gleichen Weise. Durch Erhitzen des Dialysates auf $80^{\circ}$ ging seine Wirksamkeit verloren, ohne dass dabei eine Coagulation zu Stande gekommen wäre.

Nur durch sehr vorsichtiges Ansänern mit verdünṇter Essigsäure konnte unter Zusatz von Kochsalz bei $76^{\circ}$ Coagulation erzielt werden. Durch Einengen des Dialysates im Vacuum bei einer $40^{\circ}$ nicht übersteigenden Temperatur konnte eine opalescirende Flüssigkeit von etwas höherem Agglutiningehalte gewonnen werden, als das ursprüngliche Serum. In dieser Flüssigkeit konnten Kalkniederschläge erzeugt werden, ohne dass diese die wirksame Substanz mitgerissen hätten, z. B. $5^{\mathrm{ccm}}$ Dialysat $+1 \mathrm{ccm}$ $\mathrm{CaCl}_{2} 10$ Proc. +2 cem $\mathrm{N}_{2} \mathrm{CO}_{3}$ (20 Proc.) +2 ccm $\mathrm{Na}_{2} \mathrm{HPO}_{4}$ (10 Proc.). Der Kalkniederschlag gewaschen giebt keine Agglutination, das klare Filtrat ist mit Berüeksichtigung der Verdünnung ebenso wirksam als vorher und misst 2500 Aggl.-E. Dasselbe negative Resultat hatten auch andere Versuche durch Erzeugung von Niederschlägen das Agglutinin mechanisch mitzureissen, bei welchen Bleizucker und Kalialaun verwendet werden. Insbesondere lassen sich durch Kalialaun sehr dichte Eiweissniederschläge gewinnen, die trotzdem kein Agglutinin fällen. Es dürfen dabei nur geringe Mengen von Kalialaun etwa 0.1 bis $0.2^{\mathrm{grm}}$ in Substanz auf $10 \mathrm{cem}$ Serum zugesetzt werden, da sonst der gebildete Niederschlag wieder 'in Lösung geht.

Die Thatsache, dass das Typhus-Agglutinin gar nicht oder nur in Spuren dialysirt, steht in guter Uebereinstimmung mit dem Umstande, dass auch nur solche Gewebsflüssigkeiten Agglutinin enthalten, die gleichzeitig eiweisshaltig sind. Einzelne gegentheilige Befunde sprechen nicht ohne Weiteres gegen die Colloid-Natur des Typhus-Agglutinin. Wenn z. B. Widal und Sicard im Urin eines typhösen Agglutinin nachweisen konnten, ohne dass Eiweiss auch nur in Spuren vorhanden war, so ist dabei auf folgende Verhältnisse zu achten.

Verdünnt man ein minderwerthiges Serum mit steigenden Wassermengen, so wird bald die Grenze erreicht sein, über die hinaus nur noch die Biuretprobe, nicht aber die Agglutininprüfung positiv ausfällt. Dagegen lässt sich mit hochwerthigem Serum leicht das Gegentheil zeigen. Hier werden Typhusbacillen noch in solchen Verdünnungen specifisch beein- 
flusst, bei denen die feinsten Eiweissproben versagen. Man wird deshalb bei Erhebung solcher Befunde stets die Werthigkeit des betreffenden Serums mit berücksichtigen müssen. Ist aber in einem Eiweiss enthaltenden Harn der Agglutininbefund negativ, so wird ausserdem noch daranf zu achten sein, $o b$ es sich im Wesentlichen um eine Albuminurie oder um eine Globulinurie handelt. Denn zu den Albuminen steht das TyphusAgglutinin in keinerlei Beziehung, während dieselbe zu den Globulinen jedenfalls eine sehr enge ist.

\section{Untersuchungen über die agglutinirbare Substanz der Typhusbacillen.}

Nachdem es in den angeführten Versuchen nicht gelungen war, das Typhus-Agglutinin von den Globulinen des Blutserums zu trennen, versuchte ich noch auf folgendem Wege zu einem Resultate zu gelangen.

Vorausgesetzt, dass die agglutinirbare Substanz, wie Nicolle ${ }^{1}$ nachgewiesen zu haben glaubte, in absolutem Alkohol und in Aether löslich sei, musste ihre Trennung von allen übrigen Eiweisskörpern leicht möglich sein. Zeigten die durch Hinzufügung des entsprechenden Serums gewonnenen specifischen Niederschläge, die durch Waschen mit destillirtem Wasser ebenfalls genügend gereinigt werden konnten, dann noch Eiweiss bezw. Globulincharakter, so hätte derselbe nur auf das Agglutinin bezogen werden können. Denn die zweite in absolutem Alkohol lösliche Componente müsste als vollständig frei ron Eiweiss angesehen werden.

Leider aber hat sich die dieser Ueberlegung zu Grunde liegende Angabe Nicolle's bei sorgfältiger Nachuntersuchung als nicht stichbaltig erwiesen.

Eine 70 Tage alte Typhus-Bouilloncultur, die bei $37^{\circ}$ im Brutofen belassen war und ein sehr reichliches Wachsthum aufgewiesen hatte, wurde mit der 10 fachen Menge absoluten Alkohols gefällt. Der Niederschlag wurde wiederholt zuerst mit absolutem Alkohol, dann mit wasserfreiem Aether übergossen, nach je 24 Stunden decantirt und die so erhaltenen Auszüge mit dem ersten Filtrate vereinigt. Die dadurch gewonnene alkohol-ätherische Lösung wurde im Vacuum bei $30^{\circ}$ zur Trockene eingedampft und der Rückstand in leicht alkalische Bouillon aufgenommen. Die Lösung wurde wieder mit dem 10 fachen Volumen absoluten Alkohols behandelt, im Vacuum bei $30^{\circ}$ abermals getrocknet, dann in derselben Bouillon gelöst, pukalisirt und durch 48 Stunden im Wärmeschrank auf ihre Keimfreiheit geprüft. Proben derselben wurden hierauf im Ver-

t Ch. Nicolle, a. a. 0. 
hältniss von $1: 10,5: 10$ und $10: 10$ mit einem Typhusserum von 2000 Agglutinineinheiten zusammengebracht.

In keinem der Probegläschen war nach 24 stündigem Aufenthalte im Brutofen ein Niederschlag ausgefallen.

Dagegen hatte sowoh】 die ursprüngliche Culturflüssigkeit in typischer Weise fast augenblicklich gegen das homologe Serum reagirt, als auch das direct durch ein Porcellanfilter gewonnene Filtrat in demselben Verhältniss wie oben mit Typhusserum versetzt, jedesmal nach 24 Stunden deutlich speeifische Niederschläge gebildet.

Es war also bei dieser Versuchsanordnung die agglutinirbare Substanz nicht in den alkohol-ätherischen Auszug übergegangen.

Das Experiment wurde in folgender Form noch $2 \mathrm{Mal}$ wiederholt und verrollständigt.

Von einer 42 und der schon oben erwähnten 70 tägigen TyphusBouilloncultur wurden je eine Probe direct und eine zweite nach vorausgegangener 2 stündiger Erwärmung im Wasserbade auf $60^{\circ}$ durch ein Pukalfilter geschickt.

Als nach 24stündigem Aufenthalte der betreffenden Filtrate in der Brutkammer. weder Keimentwickelung noch irgend eine Niederschlagsbildung aufgetreten war, erhielt ich in allen Versuchen bei Hinzufügung von Typhusserum ein Verhältniss von 2.5:5 nach 24 Stunden die charlteristischen Präcipitate.

Nun wurden je $50^{\mathrm{cem}}$ jedes der Filtrate in die 20 fache Menge absoluten Alkohols eingeträufelt. Die Niederschläge wurden sofort abfiltrirt, in physiologischer Kochsalzlösung aufgenommen, durch Eindampfen im Vacuum bei $30^{\circ}$ bis zur Trockene gänzlich von Alkohol befreit, der Rückstand abermals in dem ursprünglichen Volumen physiologischer NaClLösung gelöst, pukalisirt und in der üblichen Weise auf Keimfreiheit und eventuelle. spontane Niederschlagsbildung geprüft. Hierauf wurden nur die völlig klar gebliebenen je 2 cem enthaltenden Eprouvetten mit der gleichen Menge von ebenfalls so geprüften Typhusserums versetzt. Nach 24 Stunden waren in sämmtlichen Gläschen die charakteristischen Flocken aufgetreten, die sich auch unter dem Mikroskop in der noch zu beschreibenden typischen Form präsentirten. Doch war die specifische Niederschlagsbildung immerhin bei Weitem weniger intensiv in Erscheinung getreten, als in den direct aus der ursprünglichen Cultur durch Filtration keimfrei gemachten Flüssigkeiten. Controllproben mit normalem und mit Streptokokikenserum beschickt, blieben völlig unverändert.

Genau wie die alkoholischen Niederschläge wurden die alkoholischen Filtrate weiter verarbeitet. Bei $30^{\circ}$ im Vacuum zur Trockene eingedampft, der Rückstand in 50 com physiologischer Kochsalzlösung aufgenommen, 
pukalisirt und zu je 2 ecm in Proberöhrehen durch 24 Stunden bei $37^{\circ}$ stehen gelassen. Die völlig klar gebliebenen Röhrchen mit ebenso geprüfter Typhusbouillon in der gleichen Menge versetzt. Nach 24 Stunden war nirgends auch nur eine Spur von Präcipitation aufgetreten. In einzelnen Röhrchen hatten sich feine glitzernde Krystalle ausgeschieden, die sich bei mikrochemischer Prüfung als aus Cholestearintafeln bestehend erwiesen.

Aus diesen Versuchen geht hervor, dass die agglutinirbare Substanz in vollkommen wasserfreiem Alkohol und Aether nicht löslich ist. Das von dem meinen abweichende Resultat Nicolle's lässt sich wohl aus aus seiner in diesem Punkte nicht ausreichenden Versuchstechnik erklären.

Nicolle verfuhr auf folgende Weise. Filtration der BalterienBouilloncultur durch gehärtete Filter und Trocknen der Filter bei $37^{\circ}$. Sodann wurden dieselben zerschnitten und zum Theil in Alkohol, zum Theil in Aether macerirt. Hierauf wurde decantirt und die Macerationsflüssigkeit, um sie von festen Bestandtheilen zu befreien, rurch 5 Stunden centrifugirt. Die oberflächlichen Flüssigkeitsschichten wurden abgeschöpft und bei $20^{\circ}$ abgedampft. Der in leicht alkoholischer Bouillon gelöste nochmals filtrirte Rückstand wurde im Verbältniss von 1:10 mit dem homologen Serum rersetzt durch 48 Stunden bei niedriger Temperatur stehen gelassen. „leur non stérilité empêchait de les mettre à l'éture". Nach dieser Zeit waren unter dem Mikroskope Häufchen bemeribar, die mit den aus einfach filtrirten Culturen gewonnenen identisch waren und auch den aus agglutinirten „Miliroorganismen bestehenden". ganz analog erschienen.

Aus dieser Schilderung Nicolle's ist ohne Weiteres ersichtlich, dass die von ihm erhaltenen Ergebnisse nicht einwandfrei gewonnen wurden.

Er wiederholt aber auch an dieser Stelle die von ihm schon früher aufgestellte Behauptung, dass mikroskopisch die agglutinirten Mikroorganismen und die specifischen Niederschläge dasselbe gegenseitig nicht abgrenzbare Bild geben.

Nicolle ${ }^{1}$ schildert die specifischen Niederschläge und sagt von ihnen: „Ces amas sont absolument semblables à des amas microbiens; il serait impossible, si l'on n'était prévenu, de les en distinguer. Ils sont brillants, irréguliers, comme composés de particules separées, raguement arrondies ou ovalaires, d'aspect granuleux, mais soudées et comme fondues entre elles. On jurerait qu'il s'agit de microbes accolés u. s. w.".

Auf Grund meiner Beobachtungen kann ich dem nicht völlig beipflichten. Die mikroskopischen Bilder sind wohl in ihrer äusseren Form

${ }^{1}$ A. a. O. S. 166. 
einander sehr ähnlich, in ihrer Structur zeigen jedoch agglomerirte Mikroorganismen und specifische Niederschläge hinlängliche Unterschiede, um sie von einander differenciren zu können. Allerdings muss man die Vorsicht gebrauchen, die letzteren nur in solchen Medien zum Vergleiche heranzuziehen, in denen sie nach vorausgegangener Passage durch bakteriendichte Filter entstanden sind. Denn sonst werden die oft zahlreich auch in sterilen Flüssigkeiten vorhandenen todten Keime sowie andere Partikelchen vou den specifischen Niederschlägen zusammengerafft, wodurch Täuschungen entstehen können.

Betrachtet man agglutinirte Bakterien unter dem Mikroskope, so sieht man im Gesichtsfelde grössere und kleinere, unregelmässig aber ziemlich scharf begrenzte Häufchen, innerhalb welcher die oft ganz dicht an- und nebeneinander gelagerten Keime je nach ihrer Art als Stäbchen oder Kokken kenntlich bleiben. Immer zeichnen sich die Haufen durch den Gehalt an stärker lichtbrechenden Elementen aus.

Hingegen bestehen die specifischen Niederschläge aus feinsten, sehr schwach lichtbrechenden Granulis, deren Structur auch dort, wo grössere wolkige Präcipitationen erscheinen, ein vollständig amorphes Aussehen bietet.

Gerade an den kleinsten Häufchen ist der Unterschied am prägnantesten. In dem einen Falle aus wenigen, ganz scharf als solchen kenntlichen Bakterien zusammengesetzt, bilden sie in dem anderen feinste, kaum sichtbare, fast homogene Flöckchen.

Endlich fordert auch die Behauptung Nicolle's, dass die Entstehung der Agglutinine von der Aufnahme der agglutinirbaren Substanz in den Thierkörper abhängig sei, so sehr ich auch seine diesbezügliche Vorstellung theile, die Kritik heraus.

Versuche, welche diese Anschaunng beweisen sollten, müssten die beiden folgenden Cautelen erfüllen. Die agglutinirbare Substunz müsste für sich allein dem Thierkörper einverleibt werden und die Höhe der Activität des Serums wäre vor Beginn, sowie nach Abschluss eines jeden einzelnen Versuches zu messen und die Differenz beider Werthe zu bestimmen.

Der ersten Bedingung glaubte Nicolle offenbar durch die vorausgegangeve Erwärmung der zur Injection verwendeten keimfrei gemachten Culturen auf $115^{\circ} \mathrm{zu}$ genügen, indem er stillsehweigend voraussetzt, dass dadurch alle übrigen in Betracht kommenden Substanzen ausgeschaltet würden.

Obwohl nun auch das nicht ohne Weitres angenommen werden darf, so würden die von Nicolle erhaltenen Resultate für seine Vorstellung noch immer nicht als zwingende Beweise gelten können. Denn die ron 
Nicolle auf diese Weise erzielten Serumwerthe betrugen in einem Versuche bei Coli etwa 25 und in 2 Versuchen mit Typhus nicht einmal sichere 10 Agglutinineinheiten, Zahlen, deren Grösse auch von normalem Kaninchenserum gegenüber Coli und Typhus gar nicht selten erreicht wird.

Von einer Bestimmung der Wirksamkeit des Serums vor Beginn der angezogenen Experimente, die gerade bei so kleinen, den normalen nahestehenden Endwerthen unerlässlich ist, berichtet Nicolle nichts.

Die unter allen Emständen sehr geringe Grösse der Activität, die Nicolle durch Injection der erwärmten Culturfiltrate erhielt, steht in einem auffallenden Gegensatze zu der bedeutenden Potenz des Serums, die er in derselbeu oder kürzeren F'rist durch Injection derselben zu verzeichnen hatte, wenn die Erwärmung unterblieben war.

Da ich nun überdies nach Erwärmung keimfreier Typhus-Bouillonfiltrate, die, ohne dass eine solche vorausgegangen wäre, stets typische specifische Niederschläge bildeten, diese ganz regelmässig gar nicht oder nur sehr zweifelhaft auftreten sah, wenn die Erhitzung in kochendem Wasser auch nur 20 bis 35 Minuten gedauert hatte, so scheint mir die bezüglich des Typhus übrigens auch schon von $\mathrm{N}$ icolle wesentlich eingeschränkte Angabe über die hohe Widerstandsfähigkeit der agglutinirbaren Substanz gegenüber der Einwirkung hoher Temperaturen eher als noch zu weit gegriffen.

Die folgenden unter den oben erwähnten Vorsichtsmaassregeln angestellten Thierversuche beweisen, dass der die Bildung des Typhusagglutinins im Thierkörper provocirende und in der Bouilloncultur gelöste Körper in absolutem Alkohol nicht nur unlöslich ist, sondern durch die Einwirkung desselben eine weitgehende Schädigung erfährt. Für die Identität dieses Körpers mit der agglutinirbaren Substanz kann allerdings ein zwingender Beweis nicht geführt werden.

$\mathrm{Zu}$ sämmtlichen nachfolgenden Experimenten wurde eine sterile keimfreie Typhus-Bouilloncultur benutzt, die durch 4 Monate bei $37^{\circ}$ stehen gelassen und sodann dureh ein Thonfilter geschickt worden war.

I. Versuch. Kaninchen von $1400^{\mathrm{grm}}$ Gewicht. Entnahme von Blut aus der Ohrvene. Das gewonnene Serum enthält 0 Aggl.-E. Selbst das unverdünnte Serum ist nicht im Stande, in einer 24 stündigen Bouilloncultur von Typhusbacillen Unbeweglichkeit und Häufchenbildung derselben hervorzurufen.

Das Thier erhält nun täglich durch 15 Tage hindurch je $10^{\text {com }}$ der keimfreien Typhus-Bouilloncultur.

Schon am 6. Tage beträgt der Agglutinationswerth des wie früher gewonnenen Serums 200 Aggl.-E. Am 12. Tage ist er auf 1000 und am 15. Tage nach Injection von zusammen $150^{\mathrm{ccm}}$ der genannten Bouilloncultur 
auf 1700 gestiegen. Hier wurde der Versuch abgebrochen, nachdem sich die zur Injection verwendete Flüssigkeit als genügend wirksam erwiesen hatte.

II. Versuch. $200 \mathrm{~cm}$ derselben Bouilloncultur wurden keimfrei filtrirt und mit der 10 fachen Menge absoluten Alkohols gefällt.

Der Niederschlag wird durch 5 Minuten absetzen gelassen und hierauf rasch mittels eines Faltenfilters von dem Filtrat, das aufbewahrt wird, getrennt. Der mit absolutem Alkohol nachgewaschene Rückstand wird in $80^{\mathrm{cm}}$ physiologischer Kochsalzlösung aufgenommen.

Ein Kaninchen von $1345^{\mathrm{grm}}$ erhält nun ebenfalls durch 15 Tage hindurch jedesmal $5^{\mathrm{com}}$ dieser Lösung subcutan injicirt. Während das vor Beginn der Injectionen wie in dem früheren und in allen folgenden Experimenten aus der Ohrvene aufgefangene Blut einen Werth von 0 Aggl.-E. aufwies, den es auch noch am 6. Tage nach Beginn der Injectionen zeigte, war dieser am 11. Tage 80, am 12. 100 und am 15. Tage gleich 200 Aggl.-E.

III. Versuch. $200 \mathrm{~cm}$ der Typhus-Bouilloncultur werden genau in der gleichen Weise wie im vorangehenden Versuch mit dem 10 fachen Volumen absoluten Alkohols behandelt, das klare Filtrat aufbewahrt, der Rückstand nachgewaschen und noch am Filter in $30^{\mathrm{ccm}}$ physiologischer Kochsalzlösung aufgenommen.

Ein 1200 grm schweres Kaninchen, dessen Bluttserum auch unverdünnt Typhusbakterien nicht zu beeinflussen vermag, erhält 10 Tage hindurch je 2 cem dieser Lösung. Am 10. Tage wurde das Blut abermals auf seine Activität geprüft und zeigte diesmal bei einer 70 fachen Verdünnung noch charakteristische Wirkung. Am folgenden Tage wurde das Thier todt aufgefunden. Aus dem Herzen wurden einige Cubikcentimeter flüssigen Blutes gewonnen, desgleichen seröse Flüssigkeit aus der Pleura und Peritonealhöhle. Der Werth der beiden letzteren Flüssigkeiten betrug 60, der des Blutes 80 Aggl.-E.

IV: Versuch. Eine Lösung des alkoholischen Niederschlages aus $300^{\mathrm{ecm}}$ Typhus-Bouilloncultur, die ebenso wie in den Versuchen II und III bereitet wurde, wird $\mathrm{zu} 10^{\mathrm{cm}}$ durch 14 Tage hindurch einem Kaninchen von $1600^{\mathrm{grm}}$ Gewicht subcutan injicirt. Auch bei diesem Kaninchen war der ursprüngliche Serumwerth gleich Null. Am 8. Tage nach Beginn der Injectionen betrug er 20, am 12. Tage 350, auf welcher Höhe er auch am 19. Tage, wo der Versuch abgebrochen wurde, gefunden ward.

V. Versuch. Die in den Versuchen II, III und IV zurückgebliebenen alkoholischen Filtrate enthalten trotz der Fällung mit dem 10 fachen $V_{0}$ lumen Alkohol immer noch beträchtliche Spuren von Eiweiss. Deshalb wurden diese Filtrate miteinander vereinigt im Vacuum bei einer $37^{\circ}$ nicht übersteigenden Temperatur bis zur Syrupconsistenz eingedampft und hierauf abermals in $1500 \mathrm{ccm}$ absoluten Alkohols eingeträufelt. Es entsteht neuerdings ein ziemlich reichlicher Niederschlag, der auf einem Filter von der klar ablaufenden alkoholischen Lösung abgetrennt wird. Die letztere wird nochmals unter den gleichen Bedingungen im Vacuum eingeengt, mit viel Alkohol gefällt und die so erhaltene sehr geringe Fällung abfiltrirt. Die beiden so gewonnenen Niederschläge lösen sich leicht in physiologischer Kochsalzlösung. Mit einander vermischt geben sie $300 \mathrm{~cm}$ einer klaren hell- 
gelben Flüssigkeit, die nun $\mathrm{zu} 10$ bis $20 \mathrm{~cm}$ durch 15 Tage einem Kaninchen von $1100^{\mathrm{grm}}$ subcutan beigebracht wird. Der Serumwerth dieses Thieres, der vor Beginn der Einspritzungen gleich Null gewesen war, zeigte während der ganzen Dauer des Versuches trotz wiederholter Prüfung am 8., 10. und 13. Tage keine Aenderung. Am 16. Tage wurde das Thier todt aufgefunden und auch jetzt war sowohl das Herzblut, als auch die pleurale und peritoneale Flïssigkeit vollständig frei von Agglutinin.

VI. Versuch. Das letzte im V. Versuch übrig gebliebene alkoholische Filtrat, das nur noch ganz geringe Eiweissspuren enthielt, wurde durch Eindampfen im Vacuum bei 20 bis $35^{\circ}$ von Alkohol befreit. Der Rückstand in $50 \mathrm{~cm}$ Wasser gelöst und die nicht völlig klare Flüssigkeit zu je $3 \mathrm{~cm}$ 16 Tage hindurch einem Kaninchen von 1250 grm Gewicht subcutan-injicirt. Das Blutserum dieses Versuchsthieres agglutinirte vor Beginn des Experimentes Typhusbacillen noch deutlich bei 7 facher Verdünnung. Bei 10 facher Verdünnung war das Resultat völlig negativ. Genau dasselbe Ergebniss hatte die Untersuchung des Serums am 8., 11., 14. und 17. Versuchstage.

VII. Versuch. $150 \mathrm{cem}$ der keimfreien Typhus-Bouilloncultur wurden mit der 10 fachen Menge absoluten Alkohols durch 14 Tage stehen gelassen. Hierauf wird der Alkohol durch Abdampfen im Vacuum bei 20 bis $30^{\circ}$ entfernt und der Räckstand in $150^{\mathrm{ccm}}$ physiologischer Koohsalzlösung suspendirt. Ein Kaninchen von $1500 \mathrm{grm}$ Gewicht erhält in 15 Tagen je $10 \mathrm{~cm}$ dieser Lösung. Das Blutserum dieses Thieres hat weder vor noch nach Abschluss des Experimentes gegenüber Typhusbacillen agglutinirende Wirkung.

Resumieren wir die vorliegenden Versuche, so erhellt aus denselben, dass sowohl eine keimfrei gemachte mehrere Monate alte Typhus-Bouilloncultur, als auch der aus derselben gewonnene alkoholische Niederschlag Kaninchen subcutan applicirt, im Stande sind, im Blute dieser Thiere die Bildung der specifischen Typhusbacillen agglutinirenden Substianz zu verursachen. Diese Fähigkeit mangelt hingegen gänzlich sowohl den längere Zeit unter der Einwirkung des Alkohols gestandenen Filtraten, als auch insbesondere den im Alkohol auch nach wiederholter Fällung löslich gebliebenen Körpern.

Insofern die agglutinirbare Substanz in absolutem Alkohol löslich wäre, könnte sie an der Entstehung der Agglutinine nicht bethriligt sein. Ihre Unlöslichkeit in Alkohol dagegen kann nach meinen früheren Auseinandersetzungen für die Umkehrung dieser Schlussfolgerung nicht verwerthet werden.

In allen übrigen Punkten stimmen meine Beobachtungen bezüglich der agglutinirenden Substanz mit den ron Nicolle gemachten Angaben gut überein, weshalb ich auf diese einzugehen keinen Grund habe.

Obwohl durch die angeführten Untersuchungen eine Reihe von Eigenschaften der die Typhusbacillen agglutinirenden Substanz festgestellt werden konnte, ist es doch unmöglich, ein abschliessendes Urtheil über die che- 
mische Natur derselben zu fâllen. Pfeiffer und Proskauer, ${ }^{1}$ welche ähnliche Studien bezüglich der specifisch wirksamen Körper im Blutserum ron choleraimmunen Thieren angestellt haben, die sich allerdings nicht auf die Agglutinine allein beziehen, sind $z \mathfrak{u}$ dem Schlusse gelangt, dass man es wahrscheinlich mit Enzymen zu thun habe. Dagegen hält Elfstrand in den schon erwähnten Görbersdorfer Veröffentlichungen die blutkörperchen-agglutinirenden Eiweisse für ein Gemisch chemisch differenter, zum Theil den Globulinen, zum Theil den Albuminen angehörender Substanzen. Ist es mir nun schon a priori unwahrscheinlich, dass eine so specifische Wirkung mehreren chemisch differenten Individuen gleichzeitig zukomme, so wurden meine Bedenken bei Durchsicht der sehr genauen Versuchsprotocolle nur noch gesteigert. Eine 24- bis höchstens 48 stündige Dialyse, mit der sich Elfstrand begnügte, ist zu einer vollständigen Trennung der Globuline von den Albuminen gewiss nicht hinreichend. Insbesondere stehen 2 Versuche Elfstrands in directem Widerspruch. Bei Fällung eines Kochsalzcrotonextractes mit Ammonsulfat in Substanz und folgender 24 stündiger Dialyse zeigte sich sowohl das Filtrat von dem Inhalte des Dialysators als auch der in Wasser nicht gelöste Rückstand von ungefähr gleicher Wirkung.

Dasselbe Extract, mit $\mathrm{MgSO}_{4}$ in Substanz gefällt, ergab ein fast wirkungsloses Albuminfiltrat, dagègen eine sebr kräftige Crotinwirkung des in $\mathrm{NaCl}$ gelösten Niederschlages.

Wo sind in dem zweiten Versuche die wirksamen Albumine? Die ungenügende Dialyse im ersten Falle giebt wohl für diesen und eine Reihe anderer Befunde eine entsprechende Erklärung.

Es ist wichtig, auf diese Verhältnisse hinzuweisen, weil dem Parallelismus in der Wirkung auch ein solcher in dem chemischen Auf bau dieser interessanten Körper zu entsprechen scheint.

Dass dieselben zu den Proteïnsubstanzen gehören, unterliegt wohl keinem Zweifel. Ob sie aber Globuline, Enzyme oder endlich eine noch nicht nāher gekannte Gruppe von Eiweisskörpern darstellen, das ist mit Rücksicht auf den gegenwärtigen Stand der Eiweisschemie nicht mit Sicherheit $z u$ entscheiden. Es erscheint deshalb als das richtigste, sich vorläufig damit zu begnügen, das chemische Verhalten derselben so weit als möglich zu ergründen und zu beschreiben, ohne den Thatsachen durcb eine mehr oder weniger gewaltsame Classificirung Gewalt anzuthun.

Meine Untersuchungen lassen sich in folgenden Punkten zusammenfassen:

1 A. 2. 0 . 
1. Das Typhus-Agglutinin wird durch absoluten Alkohol zusammen mit den Eiweisskörpern vollkommen gefällt und bei längerer Einwirkung des Alkohols theilweise oder vollständig vernichtet.

2. Durch Neutralsalze kann das Typhus-Agglutinin aus seinen Lösungen mehr oder weniger vollständig ausgesalzen werden, wobei im Allgemeinen ein den Globulinen ähnliches Verhalten zu constatiren ist. Doch bestehen hinreichende Unterschiede, welche gegenüber der Gesammtheit der als Globuline bezeichneten Körper eine Differenzierung gestatten. Einzelne dieser Salze sind im Stande, das Typhus-Agglutinin beträchtlich zu schädigen oder zu zerstören.

3. Aehnlich wirken die Salze der Schwermetalle, welchę das TyphusAgglutinin fällen, wobei aber letzteres im Ueberschusse des Fällungsmittels wieder in Lösung geht.

4. Gegenüber der Einwirkung von Säuren oder Alkalien ist das Typhus-Agglutinin ausserordentlich empfindlich.

5. Eine Verdauung desselben durch thierische oder pflanzliche Verdanungsfermente ist nicht nachweisbar.

6. Auch eine Reihe von zum Theil kräftige proteolytische Enzyme producirender Bakterien vermügen das Typhus-Agglutinin nicht zu zerstören.

7. Bei der Dialyse verhült sich das Typhus-Aggiutinin wie andere colloide Stoffe.

8. Die agglutinirbare Substanz ist in absolutem Alkohol nicht löslich.

9. Die Entstehung des Typhus-Agglutinins im Thierkörper ist abhängig von der Einverleibung der in Alkohol unlüslichen Theile der TyphusCulturen, auch wenn letztere keimfrei gemacht worden sind. 